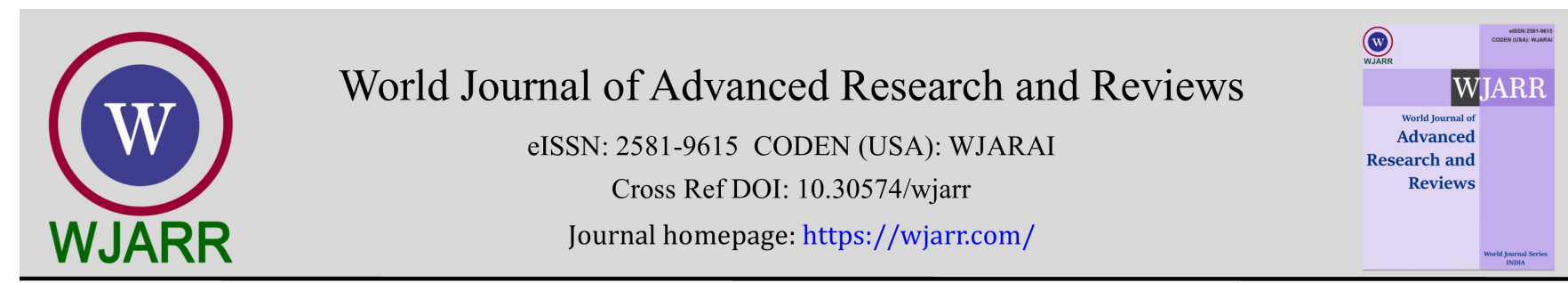

(RESEARCh ARTiCle)

\title{
A scientometric analysis of COVID-19 vaccine publications
}

\author{
Mehmet Oguzhan Ay ${ }^{1, *}$, Ali Kemal Erenler ${ }^{2}$, Ozlem Oymak Ay ${ }^{3}$, Halil Kaya ${ }^{1}$, Melih Yuksel ${ }^{1}$ and Zeynep \\ Kekec ${ }^{4}$ \\ ${ }^{1}$ University of Health Sciences, Bursa Yuksek Ihtisas Training and Research Hospital, Department of Emergency Medicine, \\ Bursa, Turkey. \\ ${ }^{2}$ Hitit University, School of Medicine, Department of Emergency Medicine, Corum, Turkey. \\ ${ }^{3}$ University of Health Sciences, Bursa City Hospital, Department of Otolaryngology, Bursa, Turkey. \\ ${ }^{4}$ Cukurova University, School of Medicine, Department of Emergency Medicine, Adana, Turkey.
}

World Journal of Advanced Research and Reviews, 2021, 09(03), 138-147

Publication history: Received on 06 February 2021; revised on 09 March 2021; accepted on 11 March 2021

Article DOI: https://doi.org/10.30574/wjarr.2021.9.3.0093

\begin{abstract}
Coronavirus disease 2019 (COVID-19) caused by the novel coronavirus SARS-CoV-2 that was declared as a pandemic has been the main subject of research all over the world. Especially studies on COVID-19 vaccines has become a hope for everyone. In this study, we aimed to analyse entire literature through Web of Science(C) Core Collection Database and reveal the current status of COVID-19 vaccine literature. We entered the keywords "COVID-19" and "vaccine" to Web of Science(C) Core Collection Database on January 20, 2021. Web of Science categories, document types, organizations, funding agencies, authors, journals, countries, languages, study fields, were investigated. A total of 2,765 publications with 24,202 citations times were involved into the study. Majority of the publications were original articles. Immunology, General Internal Medicine and Experimental Medicine Research were the top categories. Top productive Universities were Harvard University, University of California System and University of London. Dhama K. had the highest number of publications followed by Mahase E. and Baric RS. Journal of Biomolecular Structure Dynamics had published the highest number of publications. Majority of the publications were written in English. The United States of America was the most productive country followed by China and India. Research in vaccines is a growing field and is an essential component in the fight against COVID-19. Detailed analyses on vaccine publications may help researchers determine the future perspective.
\end{abstract}

Keywords: Vaccine; Scientometric Analysis; COVID-19; SARS-CoV-2; Citation analysis; Citation; Pandemic

\section{Introduction}

Coronavirus disease 2019 (COVID-19) caused by the novel coronavirus SARS-CoV-2 emerged as the major health care challenge globally since December 2019. Given the quick and steady viral spread, COVID-19 was declared as a pandemic by the World Health Organization (WHO) on March 11th, 2020 [1]. Since then, the disease has been consuming healthcare resources and forcing governments to make a decision of partial or full lockdowns. Given the fact that a definitive treatment does not exist, vaccines have emerged as a hope of humanity to prevent or limit the disease and return to normality [2]. Until today, 58 vaccines from various facilities have been developed and some of them have been declared to have more than $90 \%$ efficacy [3].

\footnotetext{
${ }^{*}$ Corresponding author: Mehmet Oguzhan Ay; Phone: +905053893239; Email: droguzhan2006@mynet.com University of Health Sciences, Bursa Yuksek Ihtisas Training and Research Hospital, Department of Emergency Medicine, Bursa, Turkey.
} 
The total number of COVID-19 cases worldwide is more than 100 million, and the pandemic led to the death of more than 2 million people [4]. Approximately 70 million COVID-19 vaccines have been administered all over the world, and this number is increasing day by day as vaccine production increases [5].

The global COVID-19 pandemic has instigated immediate and massive worldwide research activities. Literature about COVID-19 is increasing enormously [6]. Especially studies on COVID-19 vaccines has become a hope for everyone. Vaccine studies to date may shed light on the future studies. To our knowledge, this is the first scientometric analysis on COVID-19 vaccine publications.

In this study, we aimed to analyse entire literature through Web of Science $\subset$ Core Collection Database and reveal the current status of COVID-19 vaccine literature.

\section{Material and methods}

We extracted articles from Web of Science ${ }^{\odot}$ Core Collection Database by entering keywords "COVID-19" and "vaccine". Web of Science allows researchers to obtain statistical information for scientific purposes. The data base was accessed on January 20, 2021. The publications were ranked according to number of citations. Then, number of articles and citations, Web of Science categories, document types, organizations, funding agencies, authors, journals, countries, languages, study fields, were investigated.

Since this was a metadata analysis of published work, ethics committee approval was not required.

\section{Results}

A total of 2765 publications were involved. These publications were cited 24,202 times. Avarage citations per publication was 8.75 .

When Web of Science categories were considered; Immunology ( $\mathrm{n}=436 ; 15.77 \%)$, General Internal Medicine $(\mathrm{n}=308$; $11.14 \%$ ), Experimental Medicine Research ( $\mathrm{n}=290 ; 10.49 \%)$, Pharmacology ( $\mathrm{n}=272 ; 9.84 \%$ ), and Biochemistry Molecular Biology ( $\mathrm{n}=262 ; 9.48 \%$ ) were the most studied categories respectively. Of the publications, 2710 (98.01\%) were published in 2020, and 55 (1.99\%) were published in 2021.

Types of publications were mostly original articles ( $\mathrm{n}=1,371 ; 49.59 \%)$, reviews ( $\mathrm{n}=899 ; 32.51 \%)$, editorials ( $\mathrm{n}=335$; $12.12 \%)$, early access publications ( $\mathrm{n}=321 ; 11.61 \%)$, and letters $(\mathrm{n}=71 ; 2.57 \%)$.

Top productive Organizations were Harvard University ( $n=82 ; 2.97 \%)$, University of California System ( $n=72 ; 2.60 \%)$, University of London ( $n=57 ; 2.06 \%$ ), Harvard Medical School ( $n=48,1.74 \%)$, and University of Oxford ( $n=45 ; 1.70 \%)$.

United States Department of Health Human Services was the leading funding agency with 245 (8.86\%) publications, followed by National Institutes of Health NIH USA ( $\mathrm{n}=240 ; 8.68 \%)$, National Natural Science Foundation of China NSFC $(\mathrm{n}=119 ; 4.30 \%)$, NIH National Institute of Allergy Infectious Diseases NIAID ( $\mathrm{n}=71 ; 2.57 \%)$, National Science Foundation NSF ( $n=44,1.59 \%)$. See Table 1 for details. 
Table 1 Detailed List of Web of Science Categories, Document Types, Organizations and Funding Agencies.

\begin{tabular}{|c|c|c|}
\hline & & n (\%) \\
\hline \multicolumn{3}{|c|}{ Web of Science Categories } \\
\hline & Immunology & $436(15.77)$ \\
\hline & Medicine General Internal & $308(11.14)$ \\
\hline & Medicine Research Experimental & $290(10.49)$ \\
\hline & Pharmacology Pharmacy & $272(9.84)$ \\
\hline & Biochemistry Molecular Biology & $262(9.48)$ \\
\hline & Microbiology & $193(6.98)$ \\
\hline & Multidisciplinary Sciences & $192(5.94)$ \\
\hline & Infectious Diseases & $145(5.24)$ \\
\hline & Cell Biology & $144(5.21)$ \\
\hline & Public Environmental Occupational Health & $139(5.03)$ \\
\hline \multicolumn{3}{|c|}{ Document Types } \\
\hline & Original Articles & $1,371(49.58)$ \\
\hline & Reviews & $899(32.51)$ \\
\hline & Editorials & $335(12.12)$ \\
\hline & Early Access Publications & $321(11.61)$ \\
\hline & Letters & $71(2.57)$ \\
\hline \multicolumn{3}{|c|}{ Organizations } \\
\hline & Harvard University & $82(2.97)$ \\
\hline & University of California System & $72(2.60)$ \\
\hline & University of London & $57(2.06)$ \\
\hline & Harvard Medical School & $48(1.74)$ \\
\hline & University of Oxford & $47(1.70)$ \\
\hline & National Institutes of Health NIH USA & $46(1.66)$ \\
\hline & Johns Hopkins University & $45(1.63)$ \\
\hline & University of Texas System & $45(1.63)$ \\
\hline & Chinese Academy of Sciences & $42(1.52)$ \\
\hline & University of Washington & $42(1.52)$ \\
\hline & University of Washington Seattle & $42(1.52)$ \\
\hline \multicolumn{3}{|c|}{ Funding Agencies } \\
\hline & United States Department of Health Human Services & $245(8.86)$ \\
\hline & National Institutes of Health NIH USA & $240(8.68)$ \\
\hline & National Natural Science Foundation of China NSFC & $119(4.30)$ \\
\hline & NIH National Institute of Allergy Infectious Diseases NIAID & $71(2.57)$ \\
\hline & National Science Foundation NSF & $44(1.59)$ \\
\hline & Bill Melinda Gates Foundation & $35(1.27)$ \\
\hline & European Union EU & $30(1.08)$ \\
\hline & Canadian Institutes of Health Research CIHR & $29(1.05)$ \\
\hline & Wellcome Trust & $27(0.98)$ \\
\hline & National Key Research and Development Program of China & $25(0.90)$ \\
\hline
\end{tabular}


Dhama K. had the highest number of publications $(n=23,0.83 \%)$. Mahase E. was in the second rank $(n=21,0.76 \%)$, followed by Baric RS. (n=19, 0.69\%), Tiwari R. (n=16, 0.58\%) and Kumar A. (n=15, 0.54\%).

The most popular journals were as follows: Journal of Biomolecular Structure Dynamics (n=66; 2.39\%), Frontiers in Immunology ( $\mathrm{n}=62 ; 2.24 \%)$, BMJ British Medical Journal ( $\mathrm{n}=59 ; 2.13 \%)$, Human Vaccines Immunotherapeutics ( $\mathrm{n}=53$, $1.92 \%)$, Nature $(n=48,1.74 \%)$, Vaccines $(n=48,1.74 \%)$, and Vaccine $(n=45,1.63 \%)$.

When publications were investigated in terms of language, most of them were written in English ( $n=2.742 ; 97.17 \%)$. See Table 2 for details.

Table 2 Mostly Cited Authors, Journals and Mostly Used Language

\begin{tabular}{|c|c|c|}
\hline & & n (\%) \\
\hline \multicolumn{3}{|l|}{ Authors } \\
\hline & Dhama K & $23(0.83)$ \\
\hline & Mahase E & $21(0.76)$ \\
\hline & Baric RS & $19(0.69)$ \\
\hline & Tiwari R & $16(0.58)$ \\
\hline & Kumar A & $15(0.54)$ \\
\hline & Malik YS & $13(0.47)$ \\
\hline & Krammer F & $12(0.43)$ \\
\hline & Martinez DR & $12(0.43)$ \\
\hline & Wang J & $12(0.43)$ \\
\hline & Yatoo MI & $12(0.43)$ \\
\hline & Kumar P & $12(0.43)$ \\
\hline \multicolumn{3}{|l|}{ Journals } \\
\hline & Journal of Biomolecular Structure Dynamics & $66(2.39)$ \\
\hline & Frontiers in Immunology & $62(2.24)$ \\
\hline & BMJ British Medical Journal & $59(2.13)$ \\
\hline & Human Vaccines Immunotherapeutics & $53(1.92)$ \\
\hline & Nature & $48(1.74)$ \\
\hline & Vaccines & $48(1.74)$ \\
\hline & Vaccine & $45(1.63)$ \\
\hline & Journal of Medical Virology & $37(1.34)$ \\
\hline & Lancet & $35(1.27)$ \\
\hline & JAMA Journal of The American Medical Association & $32(1.16)$ \\
\hline \multicolumn{3}{|l|}{ Languages } \\
\hline & English & 2,742 (99.17) \\
\hline & French & $5(0.18)$ \\
\hline & German & $5(0.18)$ \\
\hline & Spanish & $5(0.18)$ \\
\hline & Hungarian & $3(0.11)$ \\
\hline & Polish & $2(0.07)$ \\
\hline & Portuguese & $2(0.07)$ \\
\hline & Chinese & $1(0.036)$ \\
\hline
\end{tabular}


The most productive countries were the United States of America ( $\mathrm{n}=884 ; 31.97 \%)$, People's Republic of China ( $\mathrm{n}=378$; $13.67 \%)$, India ( $\mathrm{n}=358 ; 12.95 \%)$, England ( $\mathrm{n}=257 ; 9.29 \%)$ and Italy $(\mathrm{n}=177 ; 6.40 \%)$ (Figure 1).

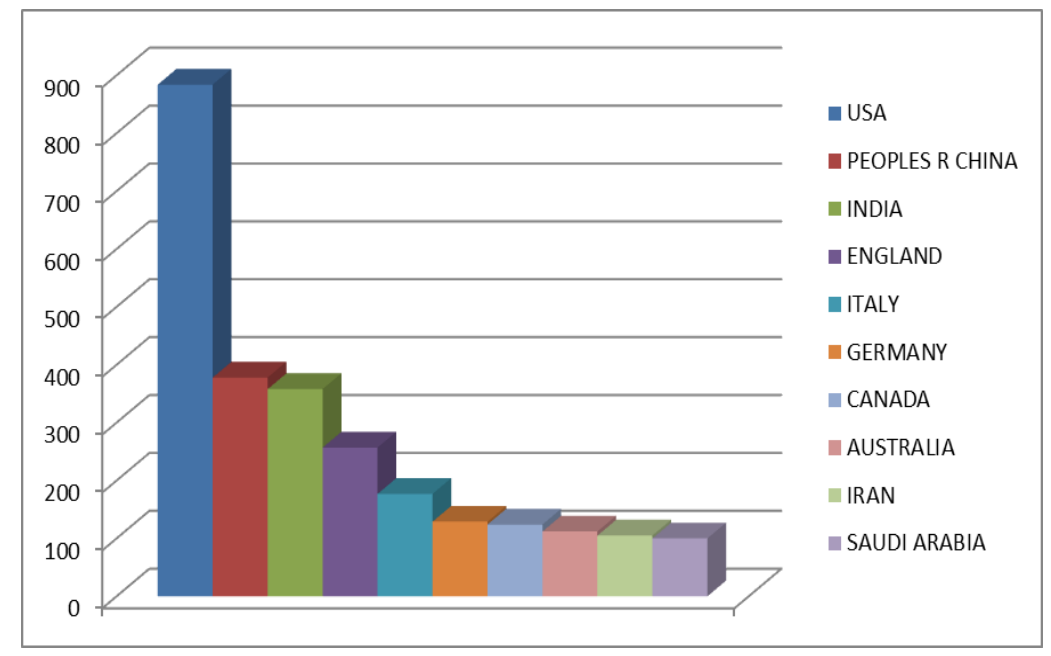

Figure 1 The most productive countries

We also provided a brief summary of the top cited 10 articles. Top 10 articles particularly focus on potential targets of vaccines and drugs. Details are presented in Table 3.

Table 3 Summary of Top 10 cited Articles Related to COVID-19 Vaccines.

\begin{tabular}{|c|c|c|c|c|c|c|c|}
\hline $\begin{array}{l}\text { Authors } \\
\text { (Reference } \\
\text { Number) }\end{array}$ & Title & $\begin{array}{l}\text { Journal } \\
\text { (Impact } \\
\text { Factor) } \\
\text { Date of } \\
\text { Publication }\end{array}$ & $\begin{array}{l}\text { Number } \\
\text { of } \\
\text { citations }\end{array}$ & $\begin{array}{l}\text { Article } \\
\text { Type }\end{array}$ & $\begin{array}{l}\text { Langu } \\
\text { age }\end{array}$ & Country & Summary \\
\hline $\begin{array}{l}\text { Ou X, Liu Y, } \\
\text { Lei X, Li P, Mi } \\
\text { D, Ren L, et } \\
\text { al. [16] }\end{array}$ & $\begin{array}{l}\text { Characterizatio } \\
\mathrm{n} \text { of spike } \\
\text { glycoprotein of } \\
\text { SARS-CoV-2 on } \\
\text { virus entry and } \\
\text { its immune } \\
\text { cross-reactivity } \\
\text { with SARS-CoV }\end{array}$ & $\begin{array}{l}\text { Nature } \\
\text { Communicatio } \\
\text { ns } \\
(12.2) \\
\text { March, } 2020\end{array}$ & 492 & $\begin{array}{l}\text { Original } \\
\text { Article }\end{array}$ & English & China & $\begin{array}{l}\text { A study on potential } \\
\text { targets that vaccines } \\
\text { should aim. Human } \\
\text { angiotensin converting } \\
\text { enzyme } 2 \text { (hACE2) is the } \\
\text { receptor for SARS-CoV-2. } \\
\text { SARS-CoV-2 enters } \\
293 / \text { hACE2 cells mainly } \\
\text { through endocytosis, that } \\
\text { PIKfyve, TPC2, and } \\
\text { cathepsin L are critical for } \\
\text { entry, and that SARS-CoV- } \\
2 \mathrm{~S} \text { protein is less stable } \\
\text { than SARS-CoV S. }\end{array}$ \\
\hline $\begin{array}{l}\text { Gordon DE, } \\
\text { Jang GM, } \\
\text { Bouhaddou } \\
\text { M, Xu J, } \\
\text { Obernier K, } \\
\text { White KM, et } \\
\text { al. } \\
{[17]}\end{array}$ & $\begin{array}{l}\text { A SARS-CoV-2 } \\
\text { protein } \\
\text { interaction } \\
\text { map reveals } \\
\text { targets for drug } \\
\text { repurposing }\end{array}$ & $\begin{array}{l}\text { Nature } \\
(42.7) \\
\text { April, } 2020\end{array}$ & 451 & $\begin{array}{l}\text { Original } \\
\text { Article }\end{array}$ & English & The USA & $\begin{array}{l}\text { The researchers cloned, } \\
\text { tagged and expressed } 26 \\
\text { of the } 29 \text { SARS-CoV-2 } \\
\text { proteins in human cells } \\
\text { and identified the human } \\
\text { proteins that physically } \\
\text { associated with each of } \\
\text { the SARS-CoV-2 proteins } \\
\text { using affinity-purification } \\
\text { mass spectrometry. They } \\
\text { identified } 332 \text { high- } \\
\text { confidence protein- } \\
\text { protein interactions }\end{array}$ \\
\hline
\end{tabular}




\begin{tabular}{|c|c|c|c|c|c|c|c|}
\hline & & & & & & & $\begin{array}{l}\text { between SARS-CoV-2 and } \\
\text { human proteins. }\end{array}$ \\
\hline $\begin{array}{l}\text { Jin Z, Du X, } \\
\text { Xu Y, Deng Y, } \\
\text { Liu M, Zhao } \\
\text { Y, et al. } \\
{[18]}\end{array}$ & $\begin{array}{l}\text { Structure of M- } \\
\text { pro from SARS- } \\
\text { CoV-2 and } \\
\text { discovery of its } \\
\text { inhibitors }\end{array}$ & $\begin{array}{l}\text { Nature } \\
(42.7) \\
\text { April,2020 }\end{array}$ & 431 & $\begin{array}{l}\text { Original } \\
\text { Article }\end{array}$ & English & China & $\begin{array}{l}\text { A programme that aimed } \\
\text { to rapidly discover lead } \\
\text { compounds for clinical } \\
\text { use, by combining } \\
\text { structure-assisted drug } \\
\text { design, virtual drug } \\
\text { screening and high- } \\
\text { throughput screening } \\
\text { was developed. The } \\
\text { programme focused on } \\
\text { identifying drug leads } \\
\text { that target main protease } \\
\text { (M-pro) of SARS-CoV-2: } \\
\text { M-pro is a key enzyme of } \\
\text { coronaviruses and has a } \\
\text { pivotal role in mediating } \\
\text { viral replication and } \\
\text { transcription, making it } \\
\text { an attractive drug target } \\
\text { for SARS-CoV-2. }\end{array}$ \\
\hline $\begin{array}{lr}\text { Grifoni } & \text { A, } \\
\text { Weiskopf } & \text { D, } \\
\text { Ramirez SI, } \\
\text { Mateus J, } \\
\begin{array}{l}\text { Dan JM,, et al. } \\
{[19]}\end{array}\end{array}$ & $\begin{array}{l}\text { Targets of } \mathrm{T} \\
\text { Cell Responses } \\
\text { to SARS-CoV-2 } \\
\text { Coronavirus in } \\
\text { Humans with } \\
\text { COVID-19 } \\
\text { Disease and } \\
\text { Unexposed } \\
\text { Individuals }\end{array}$ & $\begin{array}{l}\text { Cell } \\
(38.6) \\
\text { June, } 2020\end{array}$ & 388 & $\begin{array}{l}\text { Original } \\
\text { Article }\end{array}$ & English & The USA & $\begin{array}{l}\text { CD4(+) T cell responses } \\
\text { to spike, the main target } \\
\text { of most vaccine efforts, } \\
\text { were robust and } \\
\text { correlated with the } \\
\text { magnitude of the } \\
\text { antiSARS-CoV-2 IgG and } \\
\text { IgA titers. The M, spike, } \\
\text { and N proteins each } \\
\text { accounted for } 11 \%-27 \% \\
\text { of the total CD4(+) } \\
\text { response, with additional } \\
\text { responses commonly } \\
\text { targeting nsp3, nsp4, } \\
\text { ORF3a, and ORF8, among } \\
\text { others. For CD8(+) T cells, } \\
\text { spike and M were } \\
\text { recognized, with at least } \\
\text { eight SARS-CoV-2 ORFs } \\
\text { targeted }\end{array}$ \\
\hline $\begin{array}{lr}\text { Shereen } & \text { MA, } \\
\text { Khan } & \text { S, } \\
\text { Kazmi } & \text { A, } \\
\text { Bashir } & \text { N, } \\
\text { Siddique } & \text { R. } \\
\text { [20] } & \end{array}$ & $\begin{array}{l}\text { COVID-19 } \\
\text { infection: } \\
\text { Origin, } \\
\text { transmission, } \\
\text { and } \\
\text { characteristics } \\
\text { of human } \\
\text { coronaviruses }\end{array}$ & $\begin{array}{l}\text { Journal of } \\
\text { Advanced } \\
\text { Research } \\
\text { (4.3) } \\
\text { July, } 2020\end{array}$ & 387 & Review & English & China & $\begin{array}{l}\text { The authors summarized } \\
\text { and comparatively } \\
\text { analyzed the emergence } \\
\text { and pathogenicity of } \\
\text { COVID-19 infection and } \\
\text { previous human } \\
\text { coronaviruses, SARS- } \\
\text { CoV) and MERS-CoV. }\end{array}$ \\
\hline $\begin{array}{l}\text { Thanh Le T, } \\
\text { Andreadakis } \\
\text { Z, Kumar A, } \\
\text { Gómez } \\
\text { Román R, } \\
\text { Tollefsen S, } \\
\text { Saville M, et } \\
\text { al. } \\
\text { [21] }\end{array}$ & $\begin{array}{l}\text { The COVID-19 } \\
\text { vaccine } \\
\text { development } \\
\text { landscape }\end{array}$ & $\begin{array}{l}\text { Nature } \\
\text { Reviews Drug } \\
\text { Discovery } \\
(64.8) \\
\text { May, } 2020\end{array}$ & 308 & $\begin{array}{l}\text { News \& } \\
\text { Analysi } \\
\text { S }\end{array}$ & English & Norway & 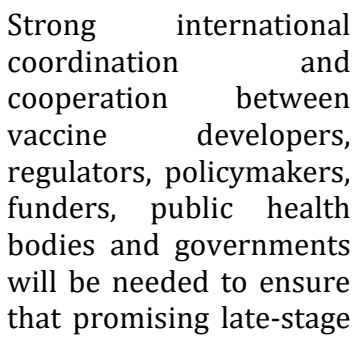 \\
\hline
\end{tabular}




\begin{tabular}{|c|c|c|c|c|c|c|c|}
\hline & & & & & & & $\begin{array}{l}\text { vaccine candidates can be } \\
\text { manufactured in } \\
\text { sufficient quantities and } \\
\text { equitably supplied to all } \\
\text { affected areas, } \\
\text { particularly low-resource } \\
\text { regions. }\end{array}$ \\
\hline $\begin{array}{l}\text { Madjid M, } \\
\text { Safavi- } \\
\text { Naeini P, } \\
\text { Solomon SD, } \\
\text { Vardeny O. } \\
{[22]}\end{array}$ & $\begin{array}{l}\text { Potential } \\
\text { Effects of } \\
\text { Coronaviruses } \\
\text { on the } \\
\text { Cardiovascular } \\
\text { System A } \\
\text { Review }\end{array}$ & $\begin{array}{l}\text { JAMA } \\
\text { Cardiology } \\
(12.7) \\
\text { July, } 2020\end{array}$ & 302 & Review & English & The USA & $\begin{array}{l}\text { It is emphasized } \\
\text { extensive efforts are } \\
\text { underway to find specific } \\
\text { vaccines and antivirals } \\
\text { against SARS-CoV-2. } \\
\text { Meanwhile, } \\
\text { cardiovascular risk } \\
\text { factors and conditions } \\
\text { should be judiciously } \\
\text { controlled per evidence- } \\
\text { based guidelines. }\end{array}$ \\
\hline $\begin{array}{l}\text { Zhang L, Liu } \\
\text { Y. } \\
{[23]}\end{array}$ & $\begin{array}{l}\text { Potential } \\
\text { interventions } \\
\text { for novel } \\
\text { coronavirus in } \\
\text { China: A } \\
\text { systematic } \\
\text { review }\end{array}$ & $\begin{array}{l}\text { Journal of } \\
\text { Medical } \\
\text { Virology } \\
\text { (2) } \\
\text { March, 2020 }\end{array}$ & 287 & Review & English & China & $\begin{array}{l}\text { The nutritional status of } \\
\text { each infected patient } \\
\text { should be evaluated } \\
\text { before the administration } \\
\text { of general treatments and } \\
\text { the current children's } \\
\text { RNA-virus vaccines } \\
\text { including influenza } \\
\text { vaccine should be } \\
\text { immunized for uninfected } \\
\text { people and health care } \\
\text { workers }\end{array}$ \\
\hline $\begin{array}{l}\text { Prompetchar } \\
\text { a E, Ketloy C, } \\
\text { Palaga T. } \\
{[24]}\end{array}$ & $\begin{array}{l}\text { Immune } \\
\text { responses in } \\
\text { COVID-19 and } \\
\text { potential } \\
\text { vaccines: } \\
\text { Lessons } \\
\text { learned from } \\
\text { SARS and MERS } \\
\text { epidemic }\end{array}$ & $\begin{array}{l}\text { Asian Pacific } \\
\text { Journal of } \\
\text { Allergy and } \\
\text { Immunology } \\
(1.7) \\
\text { March, } 2020\end{array}$ & 276 & Review & English & $\begin{array}{l}\text { Thailan } \\
\text { d }\end{array}$ & $\begin{array}{l}\text { Comparison of SARS-CoV, } \\
\text { MERS-CoV and SARS- } \\
\text { CoV-2. The review aims to } \\
\text { provide a better } \\
\text { understanding of the } \\
\text { host-pathogen } \\
\text { interaction, host immune } \\
\text { responses, and the } \\
\text { pathogen immune } \\
\text { evasion strategies. }\end{array}$ \\
\hline $\begin{array}{l}\text { Tai W, He L, } \\
\text { Zhang X, Pu J, } \\
\text { Voronin D, } \\
\text { Jiang S, et al. } \\
\text { [25] }\end{array}$ & $\begin{array}{l}\text { Characterizatio } \\
\mathrm{n} \text { of the } \\
\text { receptor- } \\
\text { binding domain } \\
\text { (RBD) of } 2019 \\
\text { novel } \\
\text { coronavirus: } \\
\text { implication for } \\
\text { development of } \\
\text { RBD protein as } \\
\text { a viral } \\
\text { attachment } \\
\text { inhibitor and } \\
\text { vaccine }\end{array}$ & $\begin{array}{l}\text { Cellular \& } \\
\text { Molecular } \\
\text { Immunology } \\
(7.1) \\
\text { March, } 2020\end{array}$ & 275 & $\begin{array}{l}\text { Original } \\
\text { Article }\end{array}$ & English & China & $\begin{array}{l}\text { The CoV spike (S) protein } \\
\text { plays the most important } \\
\text { roles in viral attachment, } \\
\text { fusion and entry, and } \\
\text { serves as a target for } \\
\text { development of } \\
\text { antibodies, entry } \\
\text { inhibitors and vaccines. } \\
\text { The researchers } \\
\text { identified the receptor- } \\
\text { binding domain (RBD) in } \\
\text { SARS-CoV-2 S protein and } \\
\text { found that the RBD } \\
\text { protein bound strongly to } \\
\text { human and bat } \\
\text { angiotensin-converting } \\
\text { enzyme } 2 \text { (ACE2) } \\
\text { receptors }\end{array}$ \\
\hline
\end{tabular}




\section{Discussion}

According to our results, the most productive country is the USA. The most popular Web of Science category is Immunology and the most popular journal is Journal of Biomolecular Structure Dynamics. There are already 2,765 publications on vaccines and COVID-19 topic in Web of Science Core Collection. This number will probably increase significantly in the near future when researchers will focus on the effects of vaccination.

To our knowledge, this is the first scientometric analysis on COVID-19 vaccine publications. A recent scientometric analysis on COVID-19 publications revealed that Medicine was the main area of publication in the field of health [7]. When publications from January 1 to July 1, 2020 were considered, epidemiology and public health interventions was the most popular study field [8]. In another study, the most popular topic was "General \&Internal; Medicine" followed by "Environmental \& Occupational Health; Public", "Nuclear Medicine \& Medical Imaging; Radiology", "Infectious Diseases", "Surgery", "Otorhinolaryngology; Surgery" and "Dermatology", respectively. The topic "Virology" was at position 8 [9]. When it comes to vaccine studies, our results revealed that field of Immunology was in the first place.

According to our results proportion of original articles was $49.59 \%$ followed by reviews $(32.51 \%)$ and editorial materials (12.12\%). In a previous study on COVID-19, 39.90\% were articles and $26.42 \%$ were editorial material [10]. Researchers preferred original articles as a method for following developments in vaccines instead of opinions and editorials.

The leading institutes were investigated, Wuhan University of Technology (Wuhan, China) followed by Università degli Studi di Milano University of Technology (Wuhan, China) were the leading institutes[9]. In our study, Harvard University, University of California System and University of London were the leading Universities published COVID-19 vaccine studies. While the East is ahead in COVID-19 studies, numerical academic superiority in vaccine studies seems to be shifting from East to West.

Top authors with the largest publications on COVID-19 were Wang Y. (0.55\%), Mahase E (0.47\%) and Li Y (0.43\%) [10]. In our study, Dhama K. had the highest number of publications $(\mathrm{n}=23,0.83 \%)$. Mahase E. was in the second rank $(\mathrm{n}=21$, $0.76 \%)$, followed by Baric RS. ( $n=19,0.69 \%)$, Tiwari R. $(n=16,0.58 \%)$ and Kumar A. $(n=15,0.54 \%)$. The most cited article was "Characterization of spike glycoprotein of SARS-CoV-2 on virus entry and its immunecross-reactivity with SARS-CoV" by Ou XY, Liu Y, Lei XB, Li P, Mi D, Ren LL et al. with 492 citations published by Nature Communications Journal on March 2020. This study aims to determine the potential targets of vaccines against coronaviruses.

In our study, the most COVID-19 vaccine studies publishing journals (impact factor of journal) were Journal of Biomolecular Structure Dynamics (4.98), Frontiers in Immunology (6.43), BMJ British Medical Journal (30.22), Human Vaccines Immunotherapeutics (3.6), Nature (42.78) and Vaccines (4.08) respectively. According to a bibliometric study on COVID-19, the journals with the largest number of publications were Journal of Medical Virology, followed by Chinese Journal of Tuberculosis and Respiratory Diseases, Journal of Travel Medicine, Journal of Clinical Medicine, Lancet, Radiology and JAMA [11].

The most productive countries in our study were the USA, China, India, England and Italy. It was previously reported that USA, China and Italy were the countries with the highest publication rates [10]. In a study, according to publications in relation to confirmed COVID-19 cases correlated deaths and total population size, the USA were leading with the highest number of both COVID-19 cases as well as related publications [9].

When top 10 articles were investigated, 6 were original articles and 4 were reviews. We determined that studies mainly focus on pathogenesis of the virus, potential target proteins for the vaccines, comparison of the current type of the virus with previous coronaviruses and host-patahogen interactions. When the literature is reviewed, vaccine production researches for SARS-CoV-2 include live attenuated vaccine, inactivated virus vaccine, subunit vaccine, viral vector-based vaccine, DNA vaccine and RNA vaccine $[12,13]$. Oxford-AstraZeneca ${ }^{\odot}$ chimpanzee adenovirus vectored vaccine, ChAdOx1 nCoV-19 (AZD1222), is known to be the first non-profit vaccine aiming for global supply [4]. The efficacy of this vaccine was reported to be $90 \%$ in those who received a low dose followed by a standard dose [14]. The vaccine BNT162b2 is also a modified RNA that encodes a version of the SARS-CoV-2 spike protein containing mutations that lock the protein into a conformation that can induce neutralizing antibody responses. The vaccine was administered a second dose 21 days following the first dose. Its efficacy was 95\% [3].

Success of in any COVID-19 vaccines mainly depend on trust and confidence. Concerns concentrate on side-effects of the vaccines. Pfizer ${ }^{\oplus}$ declared that subjects with a history of allergy to any component of the vaccine were excluded from 
the trials of their mRNA vaccine [15]. Vaccines have been hope in preventing asymptomatic transmission despite challenges related to transportation, administration and side-effects [4].

\section{Conclusion}

In conclusion, the number of COVID-19 publications has been continuously increasing after its break. It is expected that number of vaccine research publications will rise. Vaccine studies to date (January 20,2021) may shedlight on the future studies. While China has leadership on COVID-19 studies in various aspects, The Western World seems to take the leadership over when vaccine studies are considered. People are waiting for the vaccine with hope since it is supposed to be a requirement of normalization. Future studies will probably focus on efficiency and potential side effects of the vaccines when large masses of people will be vaccinated.

\section{Compliance with ethical standards}

\section{Disclosure of conflict of interest}

The authors declare that there are no conflict of interests.

\section{References}

[1] Erenler AK, Baydin A. Challenges in COVID-19 diagnosis. Bratisl Lek Listy. 2020; 121(12): 864.

[2] Rubin EJ, Longo DL. SARS-CoV-2 Vaccination - An Ounce (Actually, Much Less) of Prevention. N Engl J Med. 2020 Dec 31; 383(27): 2677-2678.

[3] Knoll MD, Wonodi C. Oxford-AstraZeneca COVID-19 vaccine efficacy. Lancet. 2021 Jan 9; 397(10269): $72-74$.

[4] Worldometer. COVID-19 Coronavirus Available andemic. https://www.worldometers.info/coronavirus/?utm_campaign=homeAdvegas1?

[5] Our World in Data. Coronavirus (COVID-19) Vaccinations. Available at: https://www.who.int/news-room/q-adetail/coronavirus-disease-(covid-19) vaccines?adgroupsurvey=\{adgroupsurvey $\}$ gclid=CjwKCAiA4rGCBhAQEiwAelVti95vIuoN8Vtf952By6jHeqIcgn PrSRpQEhcirP_jPKio5qe33Wx5UBoCCR8QAvD_BwE

[6] Grammes N, Millenaar D, Fehlmann T, Kern F, Böhm M, Mahfoud F, et al. Research Output and International Cooperation Among Countries During the COVID-19 Pandemic: Scientometric Analysis. J Med Internet Res. 2020 Dec 11; 22(12): e24514.

[7] De Sio F, Fangerau H. The Obvious in a Nutshell: Science, Medicine, Knowledge, and History. Ber Wiss. 2019 Sep; 42(2-3): 167-185.

[8] Wang J, Hong N. The COVID-19 research landscape: Measuring to pics and collaborations using scientific literature. Medicine (Baltimore). 2020 Oct 23; 99(43): e22849.

[9] Grammes N, Millenaar D, Fehlmann T, Kern F, Böhm M, Mahfoud F, et al. Research Output and International Cooperation Among Countries During the COVID-19 Pandemic: Scientometric Analysis. J Med Internet Res. 2020 Dec 11; 22(12): e24514.

[10] Martinez-Perez C, Alvarez-Peregrina C, Villa-Collar C, Sánchez-Tena MÁ. Citation Network Analysis of the Novel Coronavirus Disease 2019 (COVID-19). Int J Environ Res Public Health. 2020 Oct 21; 17(20): 7690.

[11] Zyoud SH, Al-Jabi SW. Mapping the situation of research on coronavirus disease-19 (COVID-19): a preliminary bibliometric analysis during the early stage of the outbreak. BMC Infect Dis. 2020 Aug 1; 20(1): 561.

[12] Kaur SP, Gupta V. COVID-19 Vaccine: A comprehensive status report. Virus Res. 2020 Oct 15; 288: 198114.

[13] Tsang HF, Chan LWC, Cho WCS, Yu ACS, Yim AKY, Chan AKC, et al. An Update on COVID-19 Pandemic: The Epidemiology, Pathogenesis, Prevention and Treatment Strategies. Expert Rev Anti Infect Ther. 2020 Dec 29; 112.

[14] Mahase E. Covid-19: Oxford vaccine could be 59\% effective against asymptomatic infections, analysis shows. BMJ. 2020 Dec 9; 371: m4777. 
[15] Mahase E. Covid-19: People with history of significant allergic reactions should not receive Pfizer vaccine, says regulator. BMJ. 2020 Dec 10; 371: $\mathrm{m} 4780$.

[16] Ou X, Liu Y, Lei X, Li P, Mi D, Ren L, et al. Characterization of spike glycoprotein of SARS-CoV-2 on virus entry and its immune cross-reactivity with SARS-CoV. Nat Commun. 2020 Mar 27; 11(1): 1620.

[17] Gordon DE, Jang GM, Bouhaddou M, Xu J, Obernier K, White KM, et al. A SARS-CoV-2 protein interaction map reveals targets for drug repurposing. Nature. 2020 Jul; 583(7816): 459-468.

[18] Jin Z, Du X, Xu Y, Deng Y, Liu M, Zhao Y, et al. Structure of M(pro) from SARS-CoV-2 and discovery of its inhibitors. Nature. 2020 Jun; 582(7811): 289-293.

[19] Grifoni A, Weiskopf D, Ramirez SI, Mateus J, Dan JM,, et al. Targets of T Cell Responses to SARS-CoV-2 Coronavirus in Humans with COVID-19 Disease and Unexposed Individuals. Cell. 2020 Jun 25; 181(7): 1489-1501.e15.

[20] Shereen MA, Khan S, Kazmi A, Bashir N, Siddique R. COVID-19 infection: Origin, transmission, and characteristics of human coronaviruses. J Adv Res. 2020 Mar 16; 24: 91-98.

[21] Thanh Le T, Andreadakis Z, Kumar A, Gómez Román R, Tollefsen S, Saville M, et al. The COVID-19 vaccine development landscape. Nat Rev Drug Discov. 2020 May; 19(5): 305-306.

[22] Madjid M, Safavi-Naeini P, Solomon SD, Vardeny O. Potential Effects of Coronaviruses on the Cardiovascular System: A Review. JAMA Cardiol. 2020 Jul 1; 5(7): 831-840.

[23] Zhang L, Liu Y. Potential interventions for novel coronavirus in China: A systematic review. J Med Virol. 2020 May; 92(5): 479-490.

[24] Prompetchara E, Ketloy C, Palaga T. Immune responses in COVID-19 and potential vaccines: Lessons learned from SARS and MERS epidemic. Asian Pac J Allergy Immunol. 2020 Mar; 38(1): 1-9.

[25] Tai W, He L, Zhang X, Pu J, Voronin D, Jiang S, et al. Characterization of the receptor-binding domain (RBD) of 2019 novel coronavirus: implication for development of RBD protein as a viral attachment inhibitor and vaccine. Cell Mol Immunol. 2020 Jun; 17(6): 613-620. 